\title{
A STRUCTURED E-CONTENT DEVELOPMENT FRAMEWORK USING A STRATIFIED OBJECTIVES-DRIVEN METHODOLOGY
}

\author{
Omwenga, E.I. ${ }^{1}$, Waema, T.M. ${ }^{1}$, Eisendrath, G..P.C. ${ }^{2}$ and Libotton, A. ${ }^{3}$ \\ ${ }^{1}$ School of Computing and Informatics, University of Nairobi, Kenya \\ ${ }^{2}$ EDUCO: Unit of Educational Technology, Vrije Universiteit Brussels, Belgium \\ ${ }^{3}$ Faculty of Psychology and Education, Vrije Universiteit Brussels, Belgium
}

\begin{abstract}
The paper discusses a stratified objectives-driven e-content structuring and deployment framework which is an iterative and intuitive approach to content structuring and sequencing. The model has been developed from experiences and insights gained over a four-stage content development training process involving university lecturers in liberal arts, sciences and engineering subjects. The model supports a hierarchical approach in knowledge presentation starting from the most abstract to the most specific. It is a layered structure of entities whose naming conforms to content abstractions. In this paper, we argue that the concept of Objectives is an effective tool that enables logical content breaking-up and sequencing. We demonstrate that objectives help one to think critically on what to include under specific topics. The findings indicate that objectives play a central role in providing an effective content validation mechanism. Further, collaborative efforts among homogenous groups result in the most efficient approach on training in content development.
\end{abstract}

Key Words: Objectives, objetives-driven, e-content structuring, deployment

\section{INTRODUCTION}

Although content development plays a key role in elearning, it is undoubtedly not an easy process (Jegan, 2004). It requires expert knowledge in the subject area, patience in creating the necessary objects that make up quality, interactive courseware, and a high sense of creativity in structuring and sequencing the topics to make a complete whole (Omwenga et al, 2004). In this paper we describe a model that can help in structuring chunks of contents into modules and subheadings and intuitively determine the contents for each subheading.

We define four key terms: the concept of objectives, the process being referred to as objectives-driven, the concept of e-content structuring and the issue of deployment. An objective is a clear and unambiguous description of the educational expectations from students. When written in behavioural terms, an objective will include three components: student behaviour, conditions of performance, and performance criteria (Ayot and Patel, 1992). The content that is presented should be able to bring about this behavioural change. The way it is sequenced and presented and the amount of it have an impact on the students' level of performance (Hirumi, 2002). It is for this reason that we propose a model that will help to structure the content, establish the amount of content for each topic and then sequence the topics. The objectives are broader and abstract at higher levels, and as one moves deep-down in the hierarchy they become more specific. We have coined the term Objectives-driven to describe the methodology because it is through the creation of the objectives that we are able to crystallize what is required to be taught at each level and the type and amount of content to include. If for instance, the objective is "to enable the learner visualize a 3dimensional molecular structure of a compound", then it will be helpful if the instructional material used a set of graphical models and animations to represent and explain that part of the content. On the other hand, raw content comes in large continuous chunks divided-up into sections and sub-headings. The order in which this content is covered is reflected in the sequence in which it is presented. This order is good but is devoid of human behaviour in individualized learning processes (Brusilovsky, 1998). We need to develop the courseware in such a way as to reflect the normal learning behaviour. The proposed model explained in this paper enforces good 
structuring techniques using stratified hierarchical layers that are attached to strata objects. The structuring is made possible by creating specific objectives at each level and then breaking-up each level into components that help to attain the objectives.

\section{The Objective-driven eContent Structuring and Deployment Model (ODC-SDM)}

We borrow from the concepts of using patterns to develop e-content as described in (Jegan, 2004) to develop our model. The general process of e-content development using the ODC-SDM methodology starts by first recognizing the patterns within a course on how the content is structured. The course exists within a program that leads to a degree qualification or a certificate; whichever is applicable. Structuring the course is a step-by-step process that goes through five-layered strata with each level having a number of components that should be created. The program is the highest stratum followed by course then module, unit and finally topic - in that order. The objective(s) of a course are developed and from these objectives the course is broken up into modules. Modules are like chapters in a book and each module would have an objective(s), an activity and links to other resources if need be. The next step is to break up each of these modules into smaller components (Units). Again, the module objectives are examined closely before deciding on the names of the units that will individually contribute towards attaining the module objectives. A unit could represent a section of a chapter. The next step involves dividing up the Units into topics. It is through the objective(s) of a unit that we are able to create the most atomic objectives for each topic. Each topic may have objectives, hyper-references and contextual help. The content to be covered is then associated with various topics. Any prior interaction requirements are specified at this stage.

Besides objectives, each of the levels of the structure of this model will, in addition, as the content developer may deem fit, include activities in order to enhance interactivity. However, an important attribute of a unit is the End of Unit Test which can serve as a self-assessment quiz and a way of enforcing conditions of progressing to the next unit. A unit can be equivalent to a 2 -hour lesson.

Unit topics are the entities that carry the subject matter in the learning process. They also contain objectives stated in behavioural terms. Normally, topics are short and each topic needs to express only one idea or concept. A topic will be represented by narrative text, examples, diagrams, metaphors or scenes, animations, video or audio.

The process of e-content structuring is governed by objectives. Before one creates a component one must create the relevant objective(s) first and then ask the question: "what content is required here in order to meet this objective?" Higher-level objectives are required in order to develop lower-level objectives. There are three concepts that are important in the model: a means of verifying that the objective has been attained, the objective itself, and the strata content. From a statement of the objective one should be able derive the above three concepts. Figures 1A and 1B help explain this model.

We start from the course strata since the objectives of a Program are much broader and are determined in advance. Figure 1A shows the course objective having the keyword DEMONSTRATE. Demonstrate is an active verb which is used here to describe the expected level of attainment of the cognitive knowledge. This cognitive knowledge is then broken down into modules (shown as "1:Module one") from which we derive objectives. The phrase "MEANS OF MEASUREMENT" will take such values as Demonstrate, Explain, Distinguish, etc. At this stage, we examine these module objectives with a view to finding out the key knowledge aspects that needs to be gained and hence create Units there-from. Depending on the complexity of the concepts of each aspect, we create units to explain these aspects. For each unit aspect of some knowledge to be gained, we in turn develop the topics. At this level we develop the topic objectives from each of the topics.

Figure $1 \mathrm{~B}$ on the right is an example which shows how the model can be used to break up a course on "Virtual Reality". The variables such as MEANS of MEASUREMENT and ASPECT are replaced with the actual values.

The course is called Introduction to Virtual Reality. The objective for the course contains the phrase "Conceptual Understanding". This phase is instrumental in developing the two modules as shown: "The concept of Virtual Reality" and "Elements of Virtual Reality". The same process is repeated at each of the strata. 
A Structured E-Content Development Framework using a Stratified Objectives-Driven Methodology

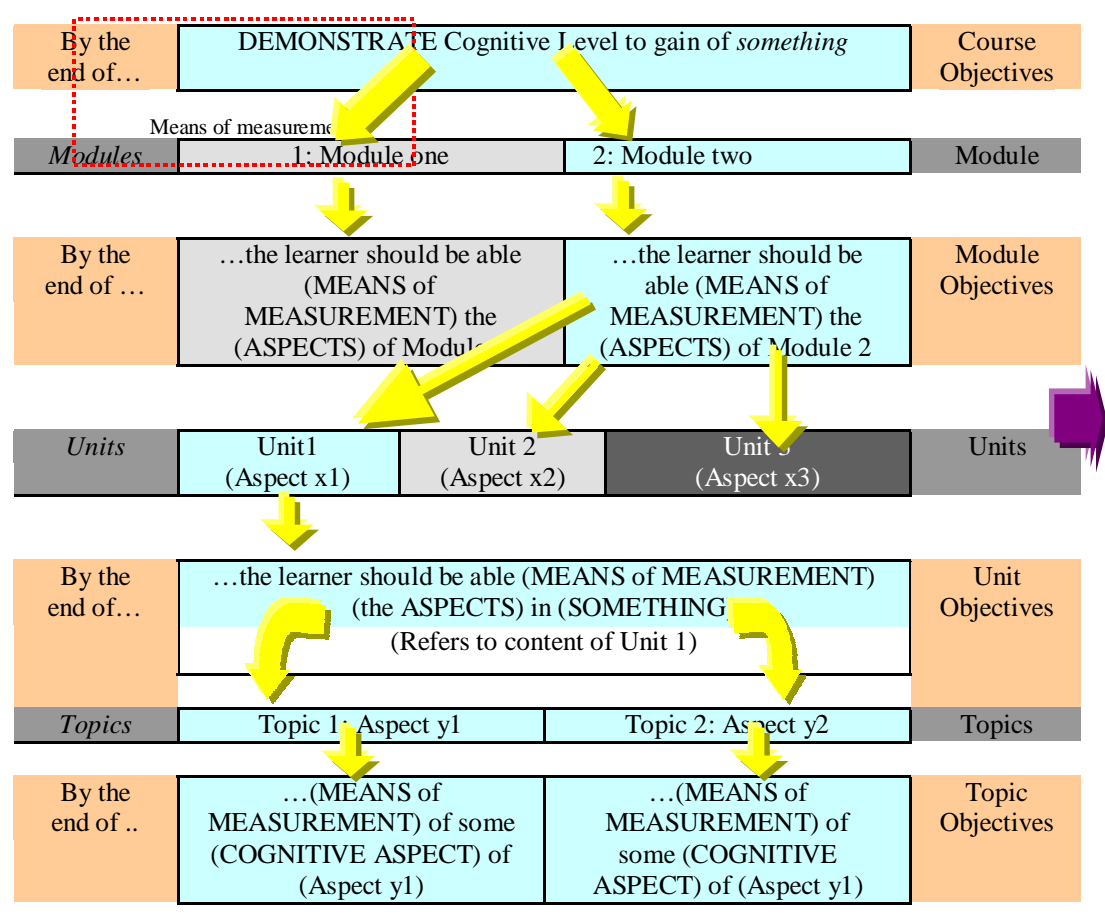

A: A model for e-content structuring using the Objectivesdriven Methodology

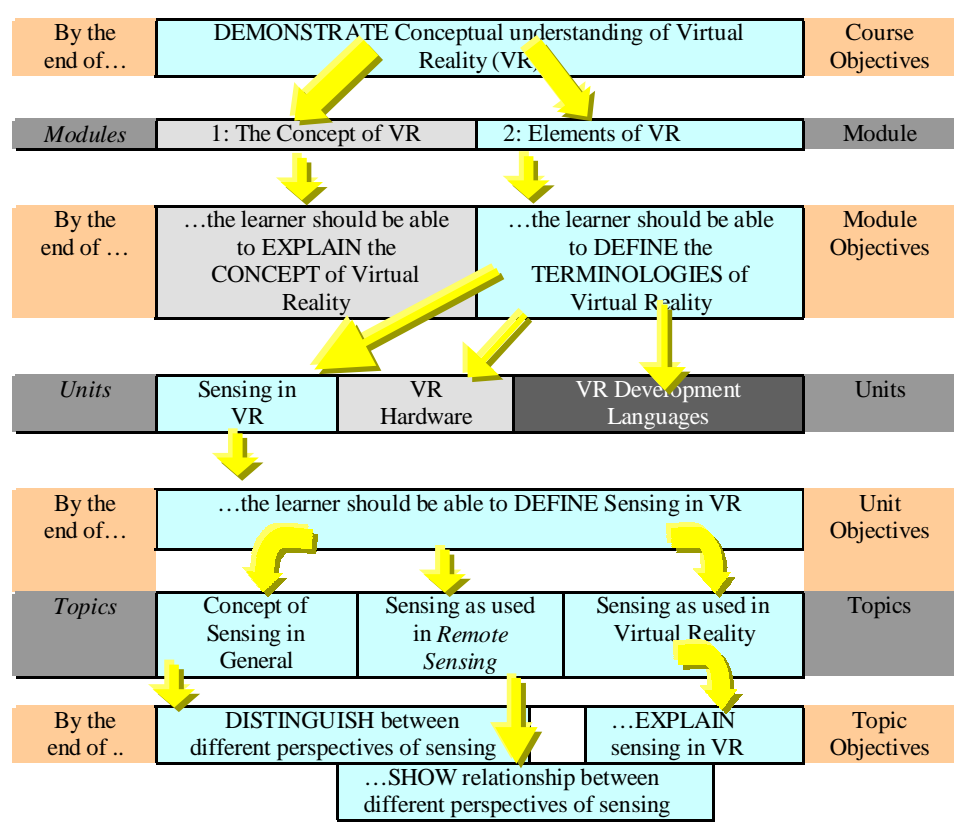

B: An Example of an Objectives-Driven Model for a Course on Virtual Reality

Figure 1: Model for e-Content Structuring using the Objective-driven Methodology 


\section{Applying ODC-SDM in a Production Environment Project Background}

In a joint project between the University of Nairobi and the Belgian Inter-Universities Council for development (VLIR), a pilot training on e-content development was initiated in March 2003 at the University of Nairobi. Initially, it was assumed that staff would easily appreciate and grasp the process. However, after the first training which took place in March 2003, it was realized that e-content development is a complex issue that requires innovation and commitment (Hirumi, 2002). Later in the year, June 2003, a second training was held using a different approach with a different set of participants - in which the ODCSDM method was applied under specific conditions. Two more training programmes in October 2003 and March 2004 were mounted using an improved version of the ODCSDM model while varying the conditions as per the experiences from previous training. The progress was monitored and a number of lessons were learnt at each stage.

The motivation to develop a framework for the e-content development process became apparent when the approach used during the first pilot training proved to be less structured and less methodical. During this pilot, the trainees (staff members) were left to work individually with only a theoretical exposition on the general structure of a course. No emphasis was made in using the concept of objectives as the beginning point in the process.

The ODC-SDM model was hence developed and deployed in all subsequent training programs in order to test its validity. There were a number of other factors (conditions) that were pertinent to the application of this model. We were to choose from either engaging trainees into collaborative groups or use Scaffolding techniques to offer support or encourage teamwork with guided discovery. Scaffolding involves giving the necessary support to start up and when competence is attained the support is removed.

\section{Collaborative Vs. Individual Effort Strategies}

Each of the four training programs proceeded in three broad phases spanning four 8-hour days. The first phase involved a fairly good treatment of the theoretical concepts of teaching and learning and the issues that are pertinent to the process. The concept of objectives, how they are developed and the role that they play in the teaching and learning process was given adequate coverage. The second stage was about structuring the content into components that would foster a pedagogically sound and effective sequencing of ideas when rendered into an electronic learning platform. Finally the third phase was on the use of an electronic learning environment (ELE), in this case wedusoft. Wedusoft, developed at the University of Nairobi, has its basic content development design architecture based on a variant of the ODC-SDM approach. Each of the training programmes represented a specific approach - findings of which were used in subsequent training programs.

\section{Findings from Use of the ODC-SDM Approach}

We describe each of the training programme cases by looking at the issues of composition of participants, training approach taken, special observation that were relevant and the lessons learnt from each case and became helpful in subsequent training programs. 
A Structured E-Content Development Framework using a Stratified Objectives-Driven Methodology

Table 1: Findings from the use of the ODC-SDM approach

\begin{tabular}{|c|c|c|c|c|c|}
\hline Case & Objective & $\begin{array}{l}\text { Composition of } \\
\text { participants }\end{array}$ & Training approach & Special Observation & Lessons Learnt \\
\hline $\begin{array}{l}\text { Scenario of } \\
\text { Individual } \\
\text { efforts (Case } \\
\text { I) }\end{array}$ & $\begin{array}{l}\text { To establish the best } \\
\text { approach to use in } \\
\text { introducing e-learning } \\
\text { training to staff; To } \\
\text { serve as a pilot }\end{array}$ & $\begin{array}{l}\text { Faculties of Science, } \\
\text { External studies } \\
\text { (Distance Education) } \\
\text { and Computer Science }\end{array}$ & $\begin{array}{l}\text { Each individual to } \\
\text { carry out tasks } \\
\text { according to template } \\
\text { given. }\end{array}$ & $\begin{array}{l}\text { Varying degree of ICT } \\
\text { usage competence - } \\
\text { training did not focus on } \\
\text { these handicap which } \\
\text { paused challenges; } \\
\text { Content structuring was } \\
\text { a challenge to all } \\
\text { especially to staff not } \\
\text { trained on pedagogy. }\end{array}$ & $\begin{array}{l}\text { Gained insight on real } \\
\text { challenges of content } \\
\text { development; Many } \\
\text { staff did not easily } \\
\text { develop a hunch on } \\
\text { how to structure } \\
\text { content. }\end{array}$ \\
\hline $\begin{array}{l}\text { Scenario of } \\
\text { applying } \\
\text { Scaffolding for } \\
\text { amorphous } \\
\text { groupings } \\
\text { (Case II) }\end{array}$ & $\begin{array}{l}\text { To provide a training } \\
\text { programme where } \\
\text { staff would learn from } \\
\text { others expertise and } \\
\text { experiences; To } \\
\text { correct previous } \\
\text { shortcoming during } \\
\text { pilot. }\end{array}$ & $\begin{array}{l}\text { Eleven faculties } \\
\text { including Science, } \\
\text { Agriculture, } \\
\text { Architecture, and Vet } \\
\text { medicine among } \\
\text { others. }\end{array}$ & $\begin{array}{l}\text { Collaboration } \\
\text { encouraged; Group } \\
\text { work according to } \\
\text { faculties; Education } \\
\text { expert in each group. } \\
\text { Five- member groups; } \\
\text { Scaffolding employed. }\end{array}$ & $\begin{array}{l}\text { Technique yielded fruits; } \\
\text { education experts } \\
\text { enabled quick results in } \\
\text { content structuring; } \\
\text { members of the groups } \\
\text { gained the skills much } \\
\text { faster; teamwork } \\
\text { dynamics helped groups } \\
\text { to keep the frustrations } \\
\text { inherent in using new } \\
\text { software low. }\end{array}$ & $\begin{array}{l}\text { Participants with no } \\
\text { formal training on } \\
\text { Education were } \\
\text { quickly acclimatized } \\
\text { into the subject area } \\
\text { through the help of } \\
\text { others; Likewise } \\
\text { those who had little } \\
\text { computer } \\
\text { background. }\end{array}$ \\
\hline $\begin{array}{l}\text { Scenario of } \\
\text { Collaborative } \\
\text { effort of } \\
\text { Teams of } \\
\text { similar } \\
\text { disciplines } \\
\text { (Case III) }\end{array}$ & \begin{tabular}{|l|} 
To employ \\
collaborative \\
techniques in e- \\
content development
\end{tabular} & \begin{tabular}{|l} 
From eight African \\
Universities; \\
Collaboration works \\
best if participants are \\
people of like minds \\
and disciplines and \\
hence participants \\
were drawn from \\
faculties of \\
Engineering and \\
Science.
\end{tabular} & $\begin{array}{l}\text { Emphasized on } \\
\text { teamwork and } \\
\text { collaboration among } \\
\text { group members; Four } \\
\text { groups each } \\
\text { comprising staff from } \\
\text { the same faculty and } \\
\text { even subject areas. }\end{array}$ & $\begin{array}{l}\text { Teamwork of } \\
\text { homogenous groups was } \\
\text { effective; Goals realized } \\
\text { within relatively shorter } \\
\text { period of time; Self-drive } \\
\text { and commitment within } \\
\text { groups was evident. } \\
\text { Groups produced mini e- } \\
\text { courses on CD at end of } \\
\text { training. }\end{array}$ & $\begin{array}{l}\text { Teamwork and } \\
\text { collaboration among } \\
\text { homogenous groups- } \\
\text { using the ODC-SDM } \\
\text { approach yields } \\
\text { quicker results; } \\
\text { Mounting training } \\
\text { programs which } \\
\text { caters for staff from } \\
\text { similar disciplines is } \\
\text { more helpful. }\end{array}$ \\
\hline $\begin{array}{l}\text { Scenario of } \\
\text { Group work } \\
\text { due to } \\
\text { Common } \\
\text { Interest (Case } \\
\text { IV) }\end{array}$ & $\begin{array}{l}\text { To apply the ODC- } \\
\text { SDM approach with } \\
\text { Professors whose level } \\
\text { on the use of } \\
\text { computers was low; to } \\
\text { find out how quickly } \\
\text { staff can attain } \\
\text { competence through } \\
\text { scaffolding and group- } \\
\text { work for staff with } \\
\text { similar background } \\
\text { grouped together by } \\
\text { common interest }\end{array}$ & $\begin{array}{l}\text { Three departments - } \\
\text { namely Animal } \\
\text { Physiology, } \\
\text { Community Health } \\
\text { and Public Health. } \\
\text { They were all senior } \\
\text { members of the } \\
\text { university community } \\
\text { who had interest in } \\
\text { educational } \\
\text { innovations especially } \\
\text { in the use of ICT to } \\
\text { support learning. }\end{array}$ & $\begin{array}{l}\text { In order to give the } \\
\text { necessary support on } \\
\text { educational and } \\
\text { Information } \\
\text { Technology issues, } \\
\text { computer technicians } \\
\text { were at hand to help } \\
\text { staff in the use of the } \\
\text { e-learning platform } \\
\text { and the education } \\
\text { experts were available } \\
\text { to help in writing } \\
\text { objectives. }\end{array}$ & $\begin{array}{l}\text { It is much easier for staff } \\
\text { to gain e-content } \\
\text { development skills if } \\
\text { they are carefully } \\
\text { grouped into } \\
\text { homogenous cells and } \\
\text { given the necessary } \\
\text { scaffolding support by } \\
\text { education experts and } \\
\text { computer technicians. }\end{array}$ & $\begin{array}{l}\text { Staff appreciated the } \\
\text { ODC-SDM } \\
\text { methodology; } \\
\text { Motivated to see } \\
\text { results of their work } \\
\text { when content is } \\
\text { rendered into the } \\
\text { ELE platform; } \\
\text { Assistance from } \\
\text { Computer } \\
\text { technicians } \\
\text { encouraged them. }\end{array}$ \\
\hline
\end{tabular}


Overall, table 1 shows that different approaches are suitable for different categories of staff. However, the ODC-SDM model works well in all cases of the e-content restructuring and development process.

\section{CONCLUSION}

We contend that there is no silver-bullet to the process of content development but the use of the objectives-driven structuring technique that has been described in this paper proved to be an effective method that enables logical breaking-up and sequencing of the content. Most of the teaching staff in most Universities are not trained in educational issues which include principles and techniques of creating behavioural objectives and therefore the transition from the "teaching concept" to the "learning concept" requires support.

Teamwork and collaborative efforts have been described in (McKnight, 2004) as best practice in online course design. We agree with this notion and further argue that individual efforts in the process of content development are useful after staff have been trained using the teamwork approach. Content development is best done if staff member of like disciplines engage in collaborative efforts to do the work. They create such great synergy that brings about self-drive and motivation to forge ahead. Thereafter staff can apply the objectives-driven model to develop electronic content. It is much more objective to validate such content as it is derived from the objectives. Important issues that are pertinent in the training process include a carefully done selection of participants, which will ensure that staff members are grouped into homogenous cells to foster teamwork.

Research has shown that staff will have inertia towards making initiatives in the use if technology unless it is critical in their preparation (Confrey et al, 2002). There is therefore a need to take care of the entry behaviour of such staff in computer skills' competence in order to alleviate any frustrations during training. This can be done by giving the necessary scaffolding support. Learning new tools and techniques is never easy; it is even more difficult for older people who do not typically see themselves as learners (Crawford 2003). Hence the idea of Scaffolding.

\section{ACKNOWLEDGEMENTS}

Many people provided assistance during the time of carrying out this study that it may not be possible for us to mention each one of them name by name. Our thanks go to them. We however wish to mention Mr. James Kariuki and Mr. Othieno Okong'o who were instrumental in ensuring that the administrative and technical issues during the training activities went on successfully. Many thanks also go to the University of Nairobi, the Belgianfunded VLIR program and UNESCO/ANSTI who provided financial support during the training activities.

\section{REFERENCES}

Ayot, H.O. \& Patel M. M. (1992). Instructional Methods. Nairobi: Educational Research and Publications LTD.

Brusilovsky, P. (1998). Adaptive Educational Systems on the World-Wide-Web: A Review of Available Technologies. WWW-Based Tutoring, 1994, 4th International Conference on Intelligent Tutoring Systems ITS'98, San Antonio, TX.

Confrey, J., Resta, P., Petrosino, A., \& Tothero, M. (2002). Inventing New Strategies for Integrating Technology into Education. Society for Information Technology and Teacher Education International Conference 2002(1), Norfolk, VA. 1726-1727.

Crawford, C. (2003). Web-Enhancing university coursework: An innovative professional development model to support a step-by-step approach towards web-enhancing courses and empowering instructors. International Journal on E-learning, 2(1), 5-13.

Hirumi, A. (2002). The design and sequencing of eLearning Interactions: A grounded approach. International Journal on E-learning, 1(1), 19-27.

Jegan, T., \& Eswaran, C. (2004). Patterns for E-learning content development. Journal of Interactive Learning Research, 15(2), 117-133.

McKnight, R. (2004). Virtual Necessities: Assessing Online Course Design. International Journal on Elearning, 3(1), 5-10.

Omwenga, E., Waema, T., \& Wagacha, P. (2004). A model for introducing and implementing e-learning for delivery of educational content within the African context. African Journal of Sciences and Technology 5(1) 35-48. 